\title{
The Artistic Journey of Yasuo Kuniyoshi
}

Smithsonian American Art Museum Renwick Gallery, Washington, DC, USA, 3 April-3o August 2015.

Yasuo Kuniyoshi's oeuvre has often been assessed as "straight and unintellectual," but as a Japanese immigrant working during the tumultuous period between the World Wars he could have jeopardized himself by openly articulating his critical thoughts against the government of the United States (30). ${ }^{1}$ He would, however, sometimes spend an entire year on a single painting, thoughtfully adjusting the composition from various perspectives to impart hidden meanings (52). With the exhibition The Artistic Journey of Yasuo Kuniyoshi, co-curators Tom Wolf and Joann Moser took a renewed look at the artist's prolific career through sixty-six of his finest works. Their individualized attention to his art shed light on Kuniyoshi's carefully calculated approach, one that touched on issues still relevant in American society-biculturalism, immigration, race, and identity.

Born in Okayama in 1889, Kuniyoshi left Japan at the early age of sixteen to evade mandatory military service. His artistic journey thus took place entirely in the us, even though he was unable to legally become a us citizen. Nevertheless, he arrived at an opportune moment; according to American art historian Lloyd Goodrich, when Kuniyoshi moved to New York from Los Angeles in 1910, artists were observing "the widespread influence of Oriental art" in European avant-garde works (20).

Kuniyoshi's encounter with Hamilton Easter Field in 1917 was a pivotal moment for the artist. An avid collector of Japanese prints and connoisseur of American Folk Art, Field believed that "it was essential for contemporary art to draw on the traditions of non-European cultures" (25). Through Field, Kuniyoshi focused on his cultural roots and began exploring flat space and multiple focal points, initially through his ink drawings. Eggplant (1921), the earliest inkon-paper work displayed in the exhibition, combined a simplified side view of an eggplant with a bird's-eye view of a dinner plate. Maintaining a conscious distance from the Analytic Cubism of a decade earlier, instead of fragmenting the objects Kuniyoshi painted the whole figure, adding a folkloric tone by incorporating decorative floral elements.

Soon he would adopt this new style in oil. Adam and Eve (1922) rendered a frontal view of Adam in the manner of naïve art, emerging from a pond

1 This and subsequent page citations in this text refer to curator Tom Wolf's exhibition catalogue The Artistic Journey of Yasuo Kuniyoshi (London: D Giles Limited; Washington, DC: Smithsonian American Art Museum, 2015). 
depicted from an aerial view. In this work, Kuniyoshi further incorporated Japanese subjects to impart new meanings to the biblical story of Genesis: a huge rock behind Eve recalls iwakura (the dwellings of animist gods), and a twoheaded white snake above Eve's apple symbolizes good fortune and prosperity. The vernacular subjects converted the fall of man in Christian doctrine into a positive beginning. Behind Eve, however, is a cow, an alter ego of the artist (Kuniyoshi was born in the year of the ox) that appears throughout his early works, here witnessing the creation myth. This hybrid style of Japanese and the Western art, manifesting his worldview, is the so-called "Kuniyoshism." By the mid-1920s, the cow disappears, and viewers become bystanders to Kuniyoshi's "inner thought" (43).

At the height of his career, Kuniyoshi's works were often compared to those of Mark Chagall, the Russian-French artist of Belarusian Jewish origin (41). Like Chagall, racialized identity was a central theme of Kuniyoshi's paintings. His cynical view toward racial segregation was elicited in Self-Portrait as a Golf Player (1927). As an artist of Japanese descent, Kuniyoshi was excluded from American golf associations and country clubs. Golf was a game he could only play as a guest. Here, he gendered his passive obedience as feminine; the Japanese golfer stands on ground that seems to look like a dismembered woman's face.

Social disadvantages in his life politicized Kuniyoshi. During the 1930 and 1940s, he served in various artist-run organizations, such as the American Artists' Congress, An American Group, and the Artists Equity Association. For the latter two, he served as president for a time, with the goal of improving the lives of fellow artists. It was during this time that Kuniyoshi began painting his dark-skinned "universal" women. Wolf interprets these scantily dressed, anxious-looking women-often holding a newspaper-as "alter egos for the artist" (55). Like the women he represented in his paintings, Kuniyoshi felt vulnerable to the pressures of a turbulent society. A pacifist, he headed the committee that organized the 1936 exhibition War and Fascism in New York and firmly opposed Japanese militarism, but after the battle of Pearl Harbor he was classified as an "enemy alien" by the government. In order to prove his loyalty he voluntarily participated in the war effort by producing violent prous propaganda images, during which time he was under strict surveillance. In the hopes of helping atomic bomb survivors after World War II, Kuniyoshi attempted to enlist in the us Army but was rejected because of his age. He also actively assisted Japanese Americans released from domestic internment camps to reintegrate $(72)$. 


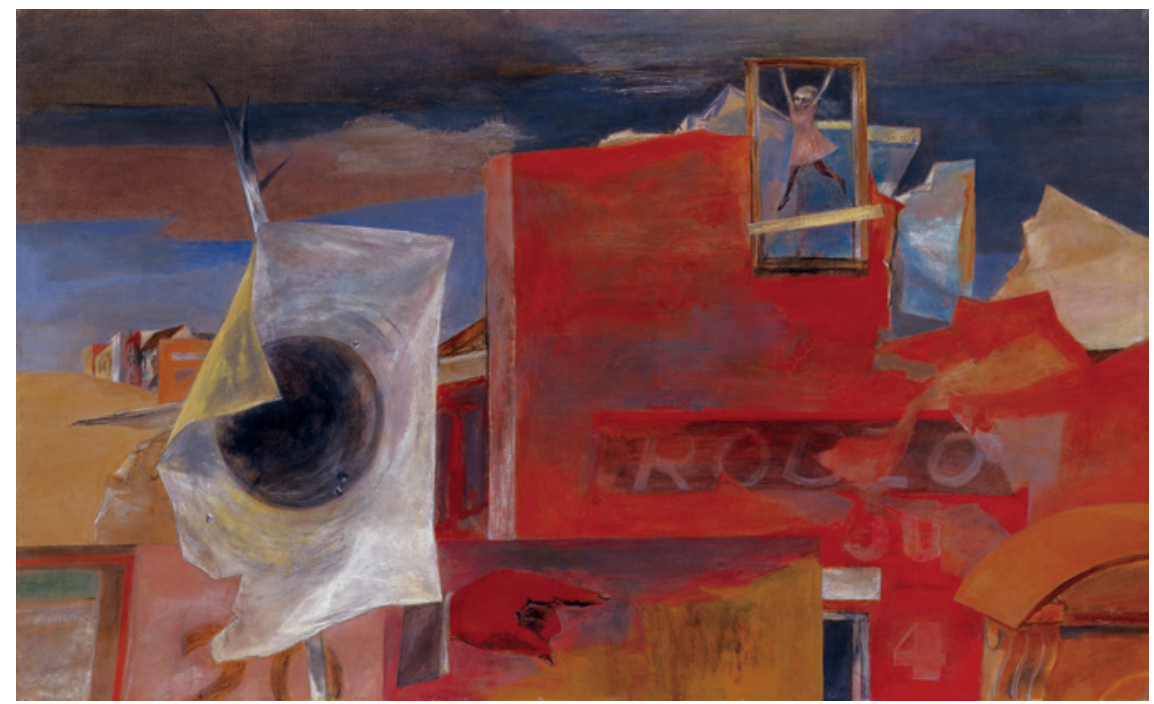

FIgURE 1 Yasuo Kuniyoshi, This is My Playground, 1947, oil on canvas, 27 inches $\times 44$ inches. FUKUTAKE COLLECTION, OKAYAMA, JAPAN.

Kuniyoshi's work gained momentum in 1948, when he was voted third-best painter in the us in a Look magazine poll. That year, the Whitney Museum of American Art honoured him with their first retrospective exhibition for a living artist, even though his figurative paintings were destined to become marginalized with the rise of Abstract Expressionism (73). Still, the experience of the war afforded the artist the impetus for one last profound series of paintings dealing with issues of surveillance, (racial) hygiene, distrust, and surrender. Often incorporating numbers and letters, Kuniyoshi's new brightly coloured paintings, done in coarse brushstrokes, recall Jasper Johns' early paintings, such as Target (1961) and Numbers in Color (1958-1959). Johns himself remembers "enjoying an exhibition [of Kuniyoshi] at the Downtown Gallery" in New York. $^{2}$

At the Art Students League, Kuniyoshi taught the Venezuelan American artist Marisol (Escobar) who would soon incorporate vernacular Pre-Columbian art into her distinctive Pop art. Due to political scrutiny, Kuniyoshi was often oblique about the meanings of his paintings but his tacitly political art seems to have inspired similarly marginalized artists during the McCarthy era (a history that still needs to be examined). The Artistic Journey of Yasuo Kuniyoshi

2 Jasper Johns, email to Maureen Pskowski, 13 September 2016, in reply to author's question. 
comprehensively illuminated an alternative view of American society as seen through Kuniyoshi's unique perspective.

\section{Midori Yamamura}

Postdoctoral Fellow, National Research Institute for Cultural Properties, Tokyo myamamura@gradcenter.cuny.edu

\section{Midori Yamamura}

is a specialist in post-wwII Asian and Asian Diaspora art in transnational contexts, feminism, and critical theory. She is the author of Yayoi Kusama: Inventing the Singular (MIT Press, 2015). And her second book, Japanese Contemporary Art Since 1989: Emergence of the Local in the Age of Globalization (University of Chicago Press, forthcoming) was nominated for the Japan Foundation Long-Term fellowship. She is the recipient of awards from the Terra Foundation, the Mellon Foundation, the Center for Place, Culture and Politics at CUNY, and the Ford Foundation.

\section{Reference}

Wolf, Tom. The Artistic Journey of Yasuo Kuniyoshi. London: D Giles Limited; Washington, DC: Smithsonian American Art Museum, 2015. 